\title{
PENGARUH WAKTU PEMBERIAN SUPLEMEN FERRO SULFAT TERHADAP KADAR SERUM FERRITINPADA TIKUS PUTIH (RATTUS NORVEGICUS) BUNTING
}

Yunda Dwi Jayanti ${ }^{1}$

Akademi Kebidanan Dharma Husada Kediri

Abstrak

Kehamilan merupakan keadaan dimana kebutuhan zat besi dalam tubuh mengalami peningkatan. Persoalan apakah suplemen zat besi perlu diberikan atau tidak masih menjadi perdebatan. Suplemen zat besi dan peningkatan cadangan zat besi dalam darah dikaitkan dengan komplikasi pada ibu hamil karena terjadi peningkatan oksidatif stres selama kehamilan. serum ferritin merupakan parameter untuk mengetahui status besi dalam tubuh. Tujuan dalam penelitian ini adalah untuk membuktikan pengaruh waktu pemberian suplemen ferro sulfat terhadap kadar serum ferritin pada tikus putih bunting.Penelitian ini merupakan penelitian eksperimental dengan jenis penelitian adalah Randomized Post Test Only Control Group Design. Penelitian ini menggunakan 24 ekor tikus bunting yang dibagi menjadi 4 kelompok. Kelompok kontrol, yaitu kelompok tikus bunting yang tidak diberi perlakuan apapun dan kelompok perlakuan 1, 2 dan 3, yaitu kelompok tikus bunting yang diberi ferro sulfat dosis $300 \mathrm{mg} /$ hari mulai hari ke 1,8 dan 15 kehamilan. Analisis data yang digunakan adalah ANOVA. Hasil penelitian didapatakn rerata kadar serum ferritin menunjukkan perbedaan bermakna baik pada kelompok kontrol dan juga kelompok perlakuan mulai pada awal, pertengahan dan akhir kehamilan(masing-masing $38.314 \pm 6.756^{\mathrm{a}} \mathrm{ng} / \mathrm{mL}, \quad 85.290 \pm 9.040^{\mathrm{b}} \mathrm{ng} / \mathrm{mL}, \quad 66.586 \pm 1.353^{\mathrm{c}} \mathrm{ng} / \mathrm{mL}$, $\left.56.002 \pm 5.229^{\mathrm{d}} \mathrm{ng} / \mathrm{ml}\right)$. Berdasarkan hasil penelitian diatas dapat disimpulkan bahwa semakin awal pemberian suplemen ferro sulfat dapat meningkatkan kadar serum ferritin.

Kata Kunci : ferro sulfat, serum ferritin, tikus bunting

Korespondensi: Jl. Raya Gampeng No. 50 Gampengrejo Kab. Kediri Jawa Timur HP: 08113313092 ,email: yunda.dj@gmail.com 


\section{PENDAHULUAN}

Kehamilan merupakan keadaan dimana kebutuhan zat besi dalam tubuh mengalami peningkatan. Apabila simpanan zat besi dalam tubuh tidak adekuat dapat mengakibatkan anemia defisiensi besi selama kehamilan ${ }^{[2,6,16]}$

Untuk mencegah anemia defisiensi besi yang terjadi pada kehamilan, pada umumnya diberikan suplemen zat besi. Setiap negara mempunyai kebijakan sendiri mengenai pemberian suplemen zat besi pada kehamilan. Pemerintah Indonesia melalui kementrian kesehatan mengatur pemberian zat besi selama hamil dengan dosis $60 \mathrm{mg}$ sebanyak 90 tablet. [8]

Persoalan apakah suplemen zat besi perlu diberikan atau tidak masih menjadi perdebatan. Suplemen zat besi dan peningkatan cadangan zat besi dalam darah dikaitkan dengan komplikasi pada ibu hamil karena terjadi peningkatan oksidatif stres selama kehamilan ${ }^{[17]}$

Melalui reaksi fenton, zat besi menghasilkan ROS yang bisa menyebabkan oksidative stres dan berakibat pada kerusakan sel pada protein, lipid dan DNA. (Zein et al., 2014). Zat besi yang berlebihan juga dipercaya dapat mengurangi perfusi plasenta yang dapat menyebabkan pre eklamsi, selain itu juga dapat menyebabkan berat lahir rendah dan kelahiran prematur ${ }^{[7]}$ Dalam penelitian yang dilakukan oleh Viteri et al (2012) terhadap ibu hamil tidak anemi yang diberikan suplemen zat besi sebanyak $60 \mathrm{mg} /$ hari mulai kehamilan ke 20 minggu, didapatkan kadar TBARSnya mengalami peningkatan, selain itu kadar $\mathrm{Hb}$, serum iron dan kadar ferritinnya juga mengalami peningkatan.

Serum ferritin merupakan parameter untuk mengetahui status besi dalam tubuh. Ferritin merupakan protein utama penyimpan besi, yang menggambarkan cadangan simpanan besi dalam tubuh. ${ }^{[9]}$

Viteri et al (2012) menyatakan kadar $\mathrm{Hb}$, serum iron dan kadar ferritin pada ibu hamil mengalami peningkatan setelah diberikan suplemen zat besi sebanyak 60 $\mathrm{mg}$ /hari mulai kehamilan ke 20 minggu sampai aterm. Sedangkan menurut penelitian Ma et al (2009) menyebutkan bahwa kadar plasma besi, $\mathrm{Hb}$ dan kadar serum ferritin pada ibu hamil mengalami peningkatan yang signifikan setelah diberikan suplemen zat besi sebanyak $60 \mathrm{mg}$ selama 2 bulan, bila dibandingkan kontrol yang hanya diberikan placebo. Dosis yang diberikan pada penelitian diatas sama dengan dosis di Indonesia, namun dari penelitian Ma et al (2009) waktu yang diberikan lebih pendek dibandingkan dengan program di Indonesia yang pemberiannya lebih lama yaitu selama hamil atau minimal 90 hari.

Status besi ikut berperan pada terjadinya komplikasi dalam kehamilan. Tingginya serum ferritin dikaikan dengan beberapa gangguan metabolik, seperti diabetes gestasional. [25] menyatakan bahwa kadar serum ferritin yang tinggi di awal kehamilan ikut berkontribusi terhadap terjadinya gangguan intolerasi glukosa pada ibu hamil yang tidak anemia. Tingginya kadar serum ferritin, serum iron, saturasi transferin dan kadar $\mathrm{Hb}$ pasca persalinan juga terdapat pada kehamilan dengan diabetes gestasional bila dibandingkan dengan kehamilan normal. ${ }^{[10]}$

Secara umum disepakati bahwa ibu menggunakan cadangan simpanan zat besi dan juga meningkatkan penyerapan zat besi untuk menyediakan kebutuhan bagi perkembangan janinnya. Tetapi, seberapa banyak dosis dan lama waktu pemberian zat besi yang sesuai dengan kebutuhan ibu hamil belum diketahui secara pasti (Gambling et al., 2004). Berdasarkan uraian di atas peneliti tertarik untuk meneliti tentang pengaruh waktu pemberian suplementasi Ferro Sulfat terhadap kadar serum iron dan kadar serum ferritin pada tikus putih (Rattus Norvegicus) bunting.

\section{BAHAN DAN METODE Metode}

Rancangan penelitian yang digunakan dalam penelitian ini adalah true experimental (eksperimental sesungguhnya). Adapun jenis yang dipakai adalah post test only control group design.

\section{Hewan coba}

Penelitian ini menggunakan 24 ekor tikus bunting yang terbagi dalam 4 kelompok, yaitu kelompok kontrol dan 3 kelompok perlakuan. Kelompok kontrol adalan kelompok tikus bunting yang tidak diberi perlakuan apapun dan kelompok perlakuan 1, 2 dan 3, yaitu kelompok tikus bunting yang diberi ferro sulfat dosis $300 \mathrm{mg} /$ hari mulai hari ke 1, 8 dan 15 kehamilan. Proses pembuntingan tikus 
dilakukan pada masa estrus. Guna mensinkronkan masa estrus, terlebih dahulu tikus betina distimulasi dengan bau-bauan atau urin dari tikus jantan dengan cara memasukkan tikus betina kedalam kandang yang sebelumnya telah ditempati oleh tikus jantan.metode ini disebut metode pheromone. Pheromone dilakukan selama 3 hari dan pada hari ke tiga dilakukan matting (kawin). Matting dilakukan pada sore hari sampai keesokan paginya. Hari dimana vaginal plug ditemukan, maka hari tersebut dikatakan sebagai hari pertama kehamilan. Pembagian waktu pemberian ferro sulfat dimodifikasi dari penelitian ${ }^{[5]}$ Pemeliharaan tikus dilakukan di Laboratorium Farmakologi FK Universitas Brawijaya Malang. Selama pemeliharaan tikus mendapatkan pakan standard an minum secara ad libitum $^{12}$. Tikus diterminasi pada hari ke 20 kehamilan.

\section{Prosedur Pengukuran serum Ferritin}

Tikus dikorbankan pada hari ke 20 kehamilan di Laboratorium Farmakologi Fakultas Kedokteran Universitas Brawijaya dengan cara anastesi menggunakan Ketamine. Darah diambil dari ventrikel jantung tikus. Serum yang diperoleh dikelompokkan berdasarkan kelompok perlakuan. Serum disentrifugasi selama 20 menit pada kecepatan $3000 \mathrm{rpm}$. Kemudian serum disimpan pada pada suhu -80 ${ }^{\circ} \mathrm{C}$. Preparasi sampel dilakukan di Laboratorium Sentral Biomedik FK Universitas Brawijaya Malang. Pengukuran kadar serum ferritin dilakukan dengan metode ELISA Satuan yang didapatkan adalah $\mathrm{ng} / \mathrm{ml}$. Analisis data yang digunakan adalah ANOVA.

\section{HASIL PENELITIAN}

\section{Pengaruh Waktu Pemberian Ferro Sulfat terhadap Kadar Serum Ferritin}

Berdasarkan hasil uji Anova one way pada data kadar serum ferritin diperoleh ada perbedaan yang bermakna rerata kadar serum ferritin keempat kelompok sampel pengamatan, hal ini ditunjukkan dengan nilai $p$-value $=0.000<\propto$. Berdasarkan hasil uji perbandingan berganda dengan uji $L S D$ menunjukkan bahwa ada perbedaan yang bermakna rerata kadar serum ferritin antarakelompok kontrol $\left(38.314 \pm 6.756^{\mathrm{a}} \mathrm{ng} / \mathrm{mL}\right)$ dengan kelompok perlakuan P1 yang diberi ferro sulfat mulai awal kehamilan $\left(85.290 \pm 90.40^{\mathrm{b}} \mathrm{ng} / \mathrm{mL}\right)$, dengan kelompok perlakuan yang diberi ferro sulfat mulai pertengahan kehamilan $\left(66.583 \pm 1.353^{\mathrm{c}} \mathrm{ng} / \mathrm{mL}\right)$, dan juga berbeda bermakna dengan kelompok perlakuan yang diberi ferro sulfat mulai akhir kehamilan yang menunjukkan nilai terkecil $\left(56.002 \pm 5.229^{\mathrm{d}}\right.$ $\mathrm{ng} / \mathrm{mL}$ ). Hal ini berarti bahwa ada pengaruh waktu pemberian suplemen ferro sulfat awal terhadap kadar serum ferritin pada tikus bunting (Rattus norvegicus).(gambar 2)

Tampak semakin akhir pemberian suplemen ferro sulfat seiring dengan penurunan rerata kadar serum ferritin antar kelompok perlakuan. Dengan kata lain semakin awal waktu pemberian suplemen ferro sulfat maka akan semakin meningkatkan kadar serum ferritin pada tikus bunting.

Untuk hasil analisis regresi pengaruh waktu pemberian suplemen ferro sulfat mulai awal kehamilan, pertengahan kehamilan, dan akhir kehamilan terhadap kadar serum ferritin pada tikus bunting (Rattus norvegicus) menjelaskan bahwa terdapat hubungan yang linier dan pengaruh yang bermakna antara waktu pemberian suplemen ferro sulfat terhadap kadar serum ferritin dengan model persamaan regresi $\hat{y}=39,68+2.2288 x$. Tampak bahwa koefisien regresi pengaruh waktu pemberian suplemen ferro sulfat terhadap serum iron (2.2288) menunjukkan nilai positif yang berarti semakin awal waktu pemberian suplemen ferro sulfat akan semakin meningkatkan kadar serum ferritin. Juga didapatkan koefisien determinasi 0.8401 yang berarti waktu pemberian suplemen ferro sulfat mempengaruhi kadar serum ferritin sebesar $84,01 \%$.

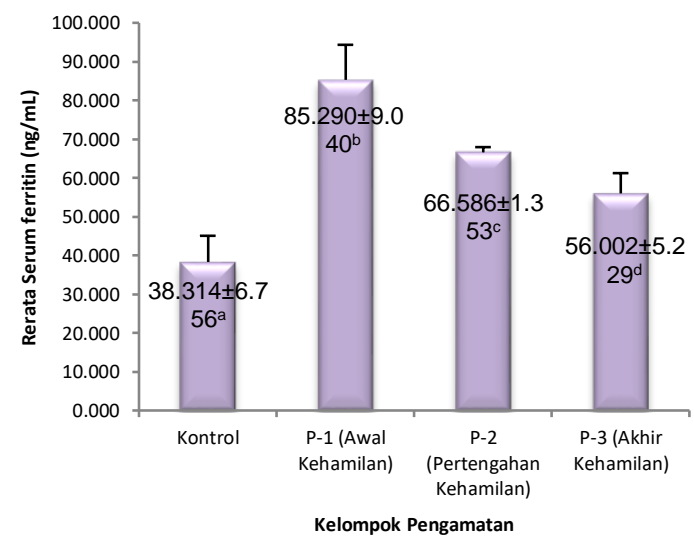

Gambar 1. Semakin awal pemberian ferro sulfat, kadar serum ferritin semakin tinggi 


\section{PEMBAHASAN}

\section{Pengaruh Waktu Pemberian Suplemen Ferro Sulfat Terhadap Kadar Serum Ferritin Pada Tikus Bunting}

Berdasarkan pada hasil analisis dengan menggunakan uji ANOVA pada data serum ferritin diperoleh ada perbedaan rerata kadar serum ferritin keempat kelompok perlakuan, hal ini ditunjukan dengan $p$-value $=0.000$. Pada uji perbandingan berganda dengan menggunakan uji LSD menunjukkan bahwa ada perbedaan yang bermakna rerata kadar serum ferritin antara kelompok kontrol dengan kelompok perlakuan yaitu tikus yang diberi suplemen ferro sulfat mulai pada awal kehamilan, pertengahan kehamilan dan juga pada akhir kehamilan. Berdasarkan nilai rerata kadar serum ferritin, nampak semakin awal pemberian ferro sulfat akan semakin meningkatkan kadar serum ferritin. Dengan kata lain semakin awal pemberian ferro sulfat pada tikus bunting dapat meningkatkan kadar serum ferritin.

Hasil ini sejalan dengan penelitian yang dilakukan oleh Gambling et al (2004) yang menyatakan bahwa tikus bunting yang diberikan suplemen zat besi sejak awal kehamilan (hari ke 0,5 kehamilan) memiliki kadar mRNA ferritin yang lebih tinggi daripada tikus yang diberi suplemen zat besi mulai kehamilan ke 7,5 dan ke 12,5.Milman et al (1997) menemukan bahwa kadar serum ferritin ibu hamil yang diberikan suplementasi lebih tinggi dibandingkan dengan kontrol.

Ferritin merupakan protein penyimpan besi utama yang terdiri dari 24 sub unit dan dikategorikan menjadi dua subtipe: subunit $\mathrm{H}$ dan subunit L. Dua puluh emapt sub unit ini menyatu dan membentuk apoferritin. Setiap molekul apoferritin dapat menyimpan kurang lebih 4500 atom besi. Feritin juga memiliki sifat enzimatik, yaitu mengkonversi ferro $\left(\mathrm{Fe}^{2+}\right)$ menjadi ferric $\left(\mathrm{Fe}^{3+}\right)$ sehingga besi bisa dimasukkan kedalam ferritin. (Torty \&Torty, 2002). Ferritin tidak hanya ditemukan di dalam liver, limpa dan sumsum tulang tapi juga di mukosa pada usus halus, plasenta, ginjal, testis dan juga pada sirkulasi darah ${ }^{[10]}$

Sintesis feritin tergantung pada kadar zat besi intraseluler. Ketika kadar zat besi rendah, sintesis feritin akan menurun. Sebaliknya, ketika kadar zat besi intraseluler tinggi, sintesis ferritin akan meningkat. Namun pada beberapa kondisi, ferritin akan tetap disintesis meskipun kadar besi intraseluler tinggi.Pengaturan sintesis ferritin melibatkan mekanisme IRE-IRP ('Iron Regulatori Element- 'Iron Regulatori Protein ). Mekanisme kontrol translasi pada sintesis ferritin dimulai pada 5' di untranslated region dari mRNA ferritin yang membentuk struktur 'stem-loop' yang disebut sebagai 'Iron Regulatori Element'(IRE). Protein sitoplasma yang sama (IRP-1 dan -2) mengikat IRE ketika tidak ada besi, tetapi IRP-1 menjadi tidak aktif atau IRP-2 menjadi terdegradasi ketika terjadi kenaikan pasokan besi. Dengan adanya ikatan antara IRE mRNA ferritin dan IRP maka sintesis ferritin tidak terjadi,tetapi dengan tidak adanya ikatan antara IRE dan IRP, maka proses pembentukan polysomes dan translasi ferritin terjadi. (Worwood,2007)

Kadar ferritin dalam serum berhubungan dengan simpanan cadangan besi dalam tubuh oleh karena itu serum ferritin digunakan sebagai parameter yang reliabel untuk mengetahui kekurangan besi dalam tubuh. (Uberos et al., 2000). Meskipun serum ferritin merupakan indikator terbaik untuk mengetahui cadangan simpanan besi, namun demikian, serum ferritin ini bukan merupakan indikator yang sensitif terhadap status besi tubuh, terhadap orang-orang yang mengalami infeksi, inflamasi atau kanker. Selain dipengaruhi oleh kadar besi dalam intraseluler, sintesis ferritin juga dipengaruhi oleh sitokin pro inflamasi, seperti TNF $\alpha$ (Tumor Necrosis Factor $\alpha$ ), Interleukin1 (IL1) dan Interleukin 6 (IL6). (Torty \&Torty, 2002). Ferritin yang tinggi dapat menstimulasi aktivasi BMP6 (Bone Morphogenetic Protein 6). BPM6 ini berperan dalam meningkatkan ekspresi hepsidin. Hepsidin yang meningkat akan mengikat FPN1 dan menyebabkan FPN-1 harus diinternalisasi dan didegradasi lisosom. Terhapusnya FPN-1 dari membran sel, secara otomatis ekspor besi ke plasma menurun. ${ }^{[3]}$

Dalam kehamilan, serum ferritin mencapai kadar tertinggi pada minggu ke 12-16 kehamilan, kemudian menurun seiring bertambahnya usia kehamilan dan mencapai puncaknya pada kehamilan trimester ketiga. ${ }^{[13,16]}$ Kadar serum ferritin menurun $32 \%$ pada kehamilan trimester pertama, 39\% pada kehamilan trimester kedua dan mencapai 53\% pada trimester ketiga ${ }^{[11]}$ Pemberian suplemen 
besi mulai awal kehamilan akan menjaga kadar serum ferritin tetap tinggi

Kadar serum ferritin yang semakin tinggi seiring dengan lamanya pemberian ferro sulfat dalam penelitian ini tidaklah sama dengan kondisi fisiologis yang terjadi selama kehamilan. Sesuai dengan penelitian yang dilakukan oleh Asif et al (2007) yang membandingkan kadar serum ferritin pada tiap trimester dalam kehamilan. Dalam penelitiannya didapatkan hasil bahwa kadar serum ferritin mencapai kadar paling rendah pada trimester kedua bila dibandingkan dengan trimester pertama dan ketiga. Tetapi kadar serum ferritin pada trimester pertama kadarnya lebih tinggi dibandingkan dengan trimester ketiga (Asif et al., 2007).Gao et al (2015) juga menyatakan bahwa kadar ferritin liver pada tikus bunting mengalami peningkatan pada awal kehamilan dan mencapai puncaknya pada kehamilan hari ke 9, tetapi kemudian mengalami penurunan drastis sampai akhir kehamilan.

Pada penelitian ini terlihat bahwa semakin awal pemberian suplemen ferro sulfat pada tikus bunting dengan dosis 5,4 mg yang setara dengan dosis $300 \mathrm{mg}$ pada manusia dapat meningkatkan kadar serum ferritin.

\section{DAFTAR PUSTAKA}

1. Asif N, Hassan K, Mahmud S, Zaheer HA, Naseem L \& Shams R. 2007. Comparison of Serum Ferritin Levels in Three Trimester Pregnancy and Their Correlation with Increasing Gravidity. International Journal of Pathology. 5 (1) : 26-30

2. Bothwell TH .2000. Iron Requirements In Pregnancy And Strategies To Meet Them. American Journal of Clinical Nutrition. 72: 257S-264S.

3. Feng Q, Mary C. Migas, Waheed A , Britton R \& Fleming R. 2012. Ferritin upregulates hepatic expression of bone morphogenetic protein 6 and hepcidin in mice. American Journal of Physiology Gastrointestinal and Liver Physiology. 302: G1397-G1404

4. Gambling L, Anderson H, \& Czopek A. 2004. Effect Of Timming Of Iron Supplemenetation On Maternal And Neonatal Growth And Iron Status Of IronDeficient Pregnant Rats. Journal of Physiology. 561(1):195-203.

5. Gambling L, Lang $\mathrm{C} \&$ McArdle HJ. 2011. Fetal Regulation of Iron transport During Pregnancy. American Journal of Clinical Nutrition. 94: 1903S-1907S

6. Hercberg G, Galan P \& Preziosi P. 2000. Consequences of Iron Deficiency in Pregnant Women. Clinical Drug Investigation. 19 (1): 1-7.

7. Javadian $\mathrm{P}$, Alimohamadi S, Gharedaghi MH \& Hantoushzadeh. 2012. Gestational Diabetes Mellitus and Iron Supplement Effects on Pregnancy Outcome. Acta Medica Iranica. 52 (5) : 385-389

8. Kemenkes R1. 2014. Peraturan Menteri Kesehatan Republik Indonesia Nomor 88 Tahun 2014 Tentang Standar Tablet Tambah Darah Bagi Wanita Usia Subur Dan Ibu Hamil. Jakarta : Kemenkes RI

9. Kohgo Y, Ikuta K, Ohtake T, Torimoto Y \& Kato J. 2008. Body iron Metabolism and Pathophysiology of Iron Overload. International Journal of Hematology. 88 (1):7-15 
Yunda Dwi Jayanti : Pengaruh Waktu Pemberian Suplemen Ferro Sulfat Terhadap Kadar Serum Ferritin

Pada Tikus Putih (Rattus Norvegicus) Bunting

10. Lao TT, Tam KF \& Chan LY. 2000. Third Trimester iron Status and Pregnancy Outcame in Non-anemic Women, Pregnancy Unfavourably Affected by Maternal Iron excess. Journal of Human Reproduction. 15 : 1843-1848

11. Lee M. 2009. Basic Skill in interpreting Laboratory Data. Fourth edition. American Society of Heakth-System Pharmacist Inc. United State

12. Millard KN, Frazer DM, Wilkins SJ \& Anderson GJ. 2004. Changes in the Expression of Intestinal Iron Transport and Hepatic Regulatory Molecules Explain the Enhanced Iron Absorption Associated with Pregnancy in the Rat. Gut Journal. 53:655-660.

13. Milman N. 2011. Oral Iron in pregnancy Not too Little and Not too Much. 2012. Journal of Pregnancy. 1-8

14. Saito H. 2012. Storage Iron Metabolism. Open access Scientific Reports. 1 (7):377340

15. Samuel P,Main EK, Mennuti MT \& Steven GG. 1987. The Origin of increased serum iron in pregnancy-induced hypertension. American Journla of Obstetry and Gynecologi.157: 721-725

16. Scholl TO. 2005. Iron Status During Pregnancy: Setting the Stage For Mother and Infant. American Journal of Clinical Nutrition. 81(suppl):1218S-1222S.

17. Sharp \& Srai, 2007. Molecular Mechanism Involved in Intestinal Iron Absorption. World Journal Gastroenterolology.13 (35): 4716-4724
18. Torti F \& Torti S. 2002. Regulation Of Ferritin Genes And Protein. Blood Journal. 99 (10): 3505-3515

19. Viteri F, Casanueva E, Tolentino MC, Frances JD \& Erazo AB. 2012. Antenatal Iron Supplements Consumed Daily Produce Oxidative Stress in Contrast Weekly Supplementation in Mexican NonAnemic Women. Reproductive Toxicology . 34 (2012) 125- 132

20. Wang J \& Pantopoulos K. 2011. Regulation of Cellular Iron Metabolism. Biochem Journal.434 :365-381.

21. WHO. 2006. Iron and Folate Supplementation. Standards for Maternal and Neonatal Departmen Of Making Pregnancy Safer. Switzerland.

22. WHO. 2012. Guideline: Daily Iron and Folic Acid Supplementation in Pregnant Women. World Health Organization: Geneva, Switzerland.

23. Woods Jr. JR. 2000. Reactive oxygen species and preterm premature rupture of membranes-a review. Placenta. 22: 38-44.

24. Worwood M. 2007. Indicators of the iron status of populations: ferritin. In: WHO, CDC. Geneva, World Health Organization. 35-74

25. Zein Salam, Rachidi Samar, Awada, Sanaa Osman M, Al-Hajje Amal, Shami N, Sharara Iman, Ali K, Salameh Pascale \& Favier I 2014. High Iron Level In Early Pregnancy Increased Glucose Intolerance. Journal of Trace Elemenst in Medicine and Biology. 9(4) :1-6 